\title{
HYDRODYNAMICS OF FLUID FLOW IN FIXED-BEDS COMPOSED OF SAND PARTICLES AND HOLLOW FIBER MEMBRANE PIPES
}

\author{
Ridwan P. Putra ${ }^{1 *}$, Dhyna Analyes Trirahayu ${ }^{1,2}$, Khairul Hadi Burhan ${ }^{1,3}$, \\ Fauzian Ichsan $^{1}$, and Mubiar Purwasasmita ${ }^{1, \dagger}$ \\ ${ }^{1}$ Department of Chemical Engineering, Faculty of Industrial Technology, Institut Teknologi Bandung, \\ Indonesia \\ ${ }^{2}$ Department of Chemical Engineering, Politeknik Negeri Bandung, Indonesia \\ ${ }^{3}$ Department of Bioengineering, School of Life Sciences and Technology, Institut Teknologi Bandung, \\ Indonesia \\ *E-mail: mg17503@ shibaura-it.ac.jp \\ †Deceased on August 18, 2017
}

\begin{abstract}
ABSTRAK
Kompos artifisial yang dibuat dari bahan polimer baru-baru ini menarik perhatian peneliti sebagai pupuk yang tahan lama dan dapat meningkatkan produktivitas tanaman tanpa menimbulkan dampak yang besar pada lingkungan. Dalam penelitian ini, pipa membran hollow fiber (HFMP) yang terbuat dari bahan polipropilen dan pasir kuarsa, masing-masing digunakan sebagai model kompos artifisial dan partikel tanah. Hidrodinamika unggun yang terdiri dari HFMP dan pasir kuarsa diteliti dengan menggunakan metode falling-head. Hasil percobaan menunjukkan bahwa unggun yang ditambahkan HFMP mengalami peningkatan porositas unggun. Unggun dengan fraksi HFMP yang lebih tinggi menunjukkan kemampuan menahan air yang lebih rendah, yang mengindikasikan kemampuan yang buruk dari bahan polipropilen dalam menahan molekul air. Sebaliknya, permeabilitas yang lebih tinggi pada unggun yang ditambahkan HFMP menunjukkan aliran cairan yang lebih baik. Studi ini mengungkap potensi kompos artifisial yang dapat diterapkan dalam teknologi pertanian berkelanjutan.
\end{abstract}

Kata kunci: Hidrodinamika, kapasitas menahan air, porositas, permeabilitas, kompos buatan

\begin{abstract}
Artificial compost fabricated from polymer materials has recently attracted considerable interest as a highly durable fertilizer that could enhance plant productivity without harming the environment. In this study, polypropylene hollow fiber membrane pipes (HFMP) and quartz sand particles were employed as models of the artificial compost and soil particles, respectively. The hydrodynamics of various volumetric ratios of beds composed of the HFMP and the quartz sand were investigated using a falling-head technique. The results show that the bed supplemented with the HFMP demonstrated enhanced bed porosity. The bed with a higher HFMP fraction exhibited slightly less water-holding capacity, which suggests the poor ability of the polypropylene material to retain water molecules. On the contrary, the higher permeability of the bed amended with the HFMP indicates improved water flow. This study unfolds the potential of artificial compost that can be implemented in sustainable agricultural technology.
\end{abstract}

Keywords: Hydrodynamics, water-holding capacity, porosity, permeability, artificial compost

\section{INTRODUCTION}

Plants are essential natural resources that provide abundant benefits to support our daily lives. The reduction of arable lands has greatly affected plant productivity around the globe, which results in the rise of global hunger, drought, and global warming. Compost 
has been considered a viable alternative to enhance plant production in limited cultivable lands by amending the soil structure and reducing nutrient leaching. Recently, our group also showed that the addition of compost to the soil could improve soil porosity and water permeability, which are necessary for sustaining the growth of soil microorganisms and facilitating nutrient transport from the soil to plant roots (Purwasasmita, 2015). The enhanced soil quality is due to the presence of microsized pipes in the compost, formed from decayed plants, that can boost water and nutrient delivery in the soil.

Despite its excellent potential to enhance plant productivity, the poor mechanical properties of compost and its fragile texture hamper its application as a highly durable fertilizer (Torres, 2011). Yamamoto et al. (2016) introduced artificial fertilizer based on urea/ureaformaldehyde polymer nanocomposites as nitrogen-loaded slow-release fertilizers. The material shows good mechanical resistance and more controlled urea release. Pourjavadi et al. (2012) reported that a novel salep phosphate-modified biopolymer could effectively improve equilibrium water absorbency, swelling rate, and nitrate release behavior in soil. These studies motivate researchers to develop artificial compost based on synthetic polymer materials that could endure harsh soil environment with controllable particle sizes.

In this work, polypropylene hollow fiber membrane pipes (HFMP) with an inner diameter of $300 \mu \mathrm{m}$ and an outer diameter of $400 \mu \mathrm{m}$ were employed as artificial compost models. Quartz sand with a size range of 18-20 mesh was used as a soil particles model. The hydrodynamic parameters (porosity, water-holding capacity, and permeability) of various beds composed of different volumetric ratios of the HFMP and the quartz sand were investigated to gain an understanding of how the micro-sized pipes affect the fluid flow characteristics in the beds. To the best of our knowledge, there are no studies that report the potential of synthetic hollow fiber membrane pipes as artificial compost.

\section{MATERIALS AND METHODS Materials and Bed Arrangement}

Quartz sand with a size range of 1820 mesh was used as the model of soil particles. Polypropylene hollow fiber membrane pipes (HFMP) with an inner diameter of $300 \mu \mathrm{m}$, an outer diameter of $400 \mu \mathrm{m}$, and a length of $10 \mathrm{~mm}$ was employed as the model of artificial compost. Potable water without further purification was used as the model of fluid that flows through the soil particles.

Several beds composed of the quartz sand and the HFMP were prepared with quartz sand to HFMP volumetric ratios of $1: 0,3: 1,1: 1,1: 3$, and $0: 1$, respectively. The combination of the quartz sand and the HFMP was used to investigate the effects on the addition of artificial compost into the soil towards the porosity, permeability, and water-holding capacity of the modeled soil particles. Both the quartz sand and the HFMP were homogeneously mixed in a container prior to each experimental measurement in order to control the reproducibility of the test.

\section{Bed Porosity Measurements}

Homogeneously mixed bed particles with a volume of $100 \mathrm{~mL}$ were poured into a $250 \mathrm{~mL}$ measuring cylinder. Subsequently, $100 \mathrm{~mL}$ of potable water was poured into the measuring cylinder little by little, not to trigger the movement of the bed particles. All of the air bubbles entrapped between the bed particles were 
expelled by gently tapping the outside wall of the measuring cylinder. The mixture was allowed to stand for $2 \mathrm{~h}$ to ensure that all bubbles were completely released. The volume of bed voids, $V_{\text {voids }}$, was calculated from the difference between the volume of the mixture after the addition of water, $V_{\text {final }}$, and the volume of the bed particles, $V_{\text {particles }}$, as justified in Equation 1.

$V_{\text {voids }}=V_{\text {final }}-V_{\text {particles }}$

The porosity of the bed, $\theta$, was calculated from the volumetric ratio of the bed voids and the bed particles (Equation 2).

$\theta=\frac{V_{\text {voids }}}{V_{\text {particles }}}$

\section{Bed Permeability and Water-holding Capacity Measurements}

The permeability of each bed was investigated using a falling-head method with an apparatus set-up shown in Figure 1. Column A with a diameter of $3 \mathrm{~cm}$ and column B with a diameter of $12 \mathrm{~cm}$ were used throughout the experiments. In column A, homogeneously mixed bed particles were poured until a height of 10 $\mathrm{cm}$ was reached. A bed-support and a strainer were positioned at the bottom and the top of column A, respectively, to hold the bed particles. Column B was used to store water that flows from column A to column B. A T-valve was stationed between column $\mathrm{A}$ and column $\mathrm{B}$ to control the water flow between both columns.

Before performing the falling-head experiments, rising-head experiments were previously conducted to saturate the bed particles with water. Column B was initially placed $30 \mathrm{~cm}$ higher than column A. Potable water with a volume of 1000 $\mathrm{mL}$ was poured into column $\mathrm{B}$ after the $\mathrm{T}$ valve connecting both columns was closed. The water was allowed to flow from column B to column A by opening the T-valve. The water climbed up the bed in column A and stopped after an equal water level with respect to the water level in column B. The T-valve was closed, and the system was allowed to stand for $1 \mathrm{~h}$ to let the water thoroughly saturate the bed particles.

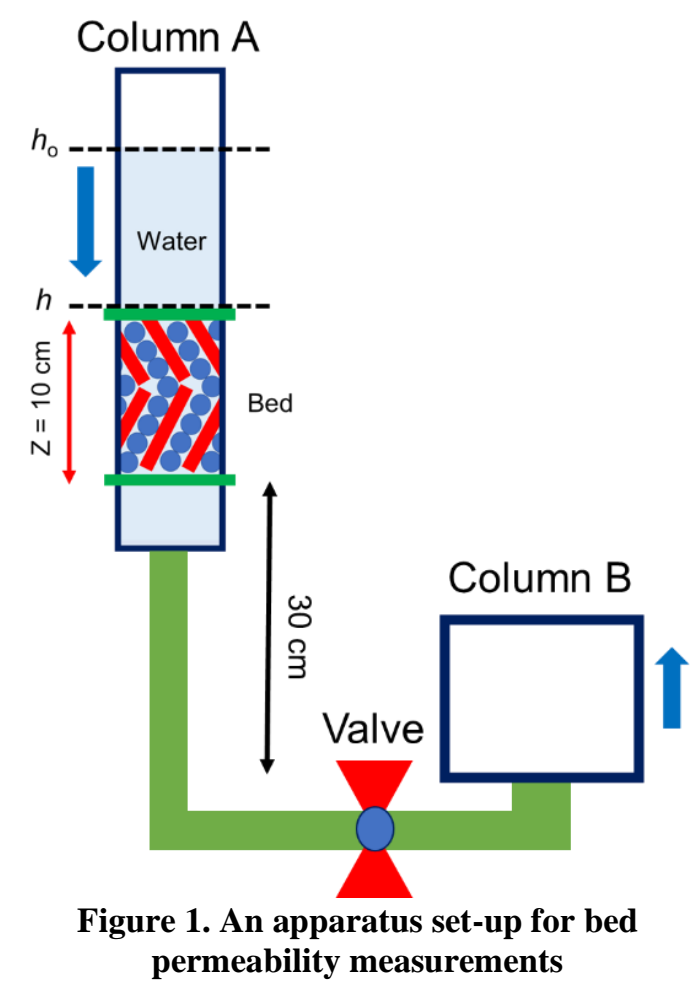

In the falling-head experiments, the position of column A and column B were reversed, which resulted in the higher elevation of column A. The T-valve connecting both columns was opened, and the water in column A started to flow down the bed particles. The time required to reach a certain height of the column was recorded, and the relationship between the water level, $h$, and time was obtained. At the end of each experiment, the remaining water was measured in a measuring cylinder to calculate the amount of water retained by the bed particles. The water-holding capacity of each bed was calculated from the amount of water retained in the bed particles $(\mathrm{mL})$ normalized by the total volume of the bed 
particles, multiplied by $100 \mathrm{~mL}$. The water-holding porosity was calculated from the ratio of the amount of water retained in the bed to the total volume of the bed particles. The unwetted porosity was calculated from the difference between the bed porosity and the waterholding porosity.

The flow of water entering the bed, $Q_{i n}$, is justified in Equation (3).

$Q_{\text {in }}=-A \times \frac{d h}{d t}$

Where $A$ is the cross-section area of the bed, $h$ is the water level at a given time, and $t$ is time. From Darcy's law, the flow out, $Q_{o u t}$, is stated in Equation (4).

$Q_{\text {out }}=\frac{B \times \Delta P}{\mu \times Z} \times A$

Where $B$ is Darcy's permeability, $\Delta P$ is the pressure drop, $\mu$ is the dynamic viscosity of water $(0.0089 \mathrm{~g} / \mathrm{cm} \cdot \mathrm{s}$ at $\left.25^{\circ} \mathrm{C}\right)$, and $Z$ is the height of the bed $(10$ $\mathrm{cm})$. The pressure drop can be stated in Equation (5).

$\Delta P=\rho \times g \times h$

Where $\rho$ is the density of water $\left(0.997 \mathrm{~g} / \mathrm{cm}^{3}\right.$ at $\left.25^{\circ} \mathrm{C}\right)$ and $g$ is the gravitational constant $\left(980 \mathrm{~cm} / \mathrm{s}^{2}\right)$. By substituting Equation (5) to Equation (4), Equation (6) was obtained.

$Q_{\text {out }}=\frac{B \times \rho \times g \times h}{\mu \times Z} \times A$

According to the continuity principle, the rate of water flow entering the column is equal to the rate of water flow out.

$Q_{\text {in }}=Q_{\text {out }}$
By substituting Equation (3) and (6) to Equation (7), Equation (8) was attained.

$-\frac{d h}{d t}=\frac{B}{\mu} \times \frac{\rho \times g \times h}{Z}$

Equation (8) can be rearranged and integrated to yield Equation (12).

$\frac{d h}{h}=-\frac{B}{\mu} \cdot \frac{\rho g}{Z} d t$

$\int_{h_{o}}^{h} \frac{d h}{h}=-\frac{B}{\mu} \cdot \frac{\rho g}{Z} \int_{0}^{t} d t$

$\ln h-\ln h_{o}=-\frac{B}{\mu} \cdot \frac{\rho g}{Z} t$

$-\ln \left(\frac{h}{h_{o}}\right)=\frac{B}{\mu} \cdot \frac{\rho g}{Z} t$

The gradient of the line $(K)$, which is equal to $\frac{B}{\mu} \cdot \frac{\rho g}{Z}$, can be obtained by plotting $-\ln \left(\frac{h}{h_{o}}\right)$ vs $t$. The value was further used to determine the permeability of the bed $(B)$.

\section{RESULTS AND DISCUSSION Bed Porosity}

The porosity of the beds composed of quartz sand as the spherical particles and HFMP as the tubular particles are summarized in Table 1 . The porosity of the bed increased considerably with the addition of tubular particles. The results indicate that the addition of the HFMP to the bed tends to enlarge the interparticle spaces formed by the spherical and the tubular particles. The addition of the HFMP to the bed composed of quartz sand is likely to disrupt the ordered quartz sand particle arrangement, which results in the enhanced bed porosity. The existence of $300 \mu \mathrm{m}$-sized channels in the HFMP also contributes to the increased porosity of the bed. The results are in good agreement with our previous study employing compost as the tubular particles and soil as the spherical particles (Purwasasmita, 2015). Pambayun et al. (2015) also found that the addition of 
compost to the soil will increase the porosity of the bed from 0.60 , for the untreated soil, to 0.75 , for the pure compost medium.

Table 1. Porosity of beds composed of various volumetric ratios of quartz sand particles and HFMP

\begin{tabular}{cc}
\hline $\begin{array}{c}\text { Fraction of } \\
\text { HFMP (v/v) }\end{array}$ & Porosity \\
\hline 0 & \\
\hline 0.25 & 0.444 \\
0.50 & 0.521 \\
0.75 & 0.592 \\
1 & 0.670 \\
\hline
\end{tabular}

The enhanced porosity in soil may provide more space in the soil, resulting in the improved $\mathrm{CO}_{2}$ exchange from the soil to the atmosphere, produced from the respiration of plant roots and the degradation of organic matters ( $\mathrm{Yu}$, 2015). In another study, Yan et al. (2016) investigated the relationship between microbial respiration to investigate organic carbon degradation in soil, $\mathrm{CO}_{2}$ production and emission, as well as their other effects on climate change. The research indicates that porosity rise can efficiently enhance the diffusion of substances between the atmosphere and the soil substrate, hence promotes heterotrophic respiration. Zhang et al. (2019) also reported that soil supplemented with compost could increase the bioavailability components present in the soil, which are triggered by the increase of interparticle spaces and the existence of micro-sized tubular channels. The nutrients stored in the soil spaces can boost soil fertility, resulting in enhanced plant productivity.

\section{Water-holding Capacity}

The water-holding capacities of the beds obtained upon the permeability measurements are shown in Figure 2. The water-holding capacity of the bed per 100 $\mathrm{mL}$ of the bed particles slightly decreased from $19.82 \mathrm{~mL}$ to $14.15 \mathrm{~mL}$ for the beds composed of unamended quartz sand and pristine HFMP, respectively. The results are contrary to a study conducted by Fauzan et al. (2020), which shows that soil amendment with compost increases the water-holding capacity of the soil. The reduction of the water-holding capacity in the bed supplemented with the HFMP is expected due to the higher porosity of the bed, which is less likely to retain water. Higher hydrophobicity of the HFMP, which are fabricated from polypropylene material, is also a factor that affects the ability of the particles to hold a certain amount of water (Kahavita, 2019). Quartz sand, mainly composed of $\mathrm{SiO}_{2}$, is more hydrophilic and tends to retain water molecules (Tschapek, 1983). Relatively thick HFMP with an inner diameter of $300 \mu \mathrm{m}$ and a thickness of 50 $\mu \mathrm{m}$ also lowers the likelihood of the HFMP storing water inside the channels.

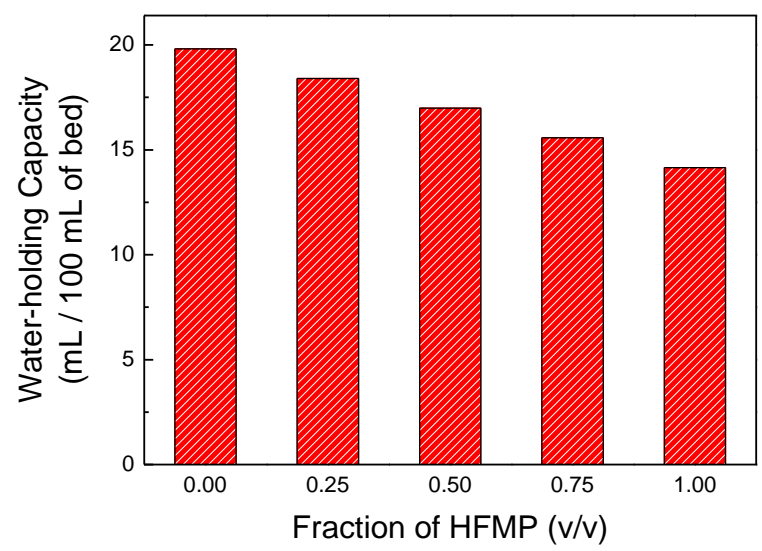

Figure 2. Water-holding capacities of beds composed of various volumetric ratios of quartz sand particles and HFMP

The slightly reduced water-holding capacity of the bed with added HFMP is somewhat a good indicator in the fabrication of artificial compost towards improved soil quality. Yan et al. (2016) reported that soil with low moisture content shows a higher heterotrophic respiration rate due to accelerated oxygen delivery in the gas phase. Mosaddeghi et 
al. (2000) studied that soil with high moisture content could lead to severe compaction of the soil particles. Soil compaction is considered soil degradation that alters soil structure and hinders air circulation (Nawaz, 2013). The results indicate that the artificial compost design that can hold an adequate amount of water needed by plants is more desirable. The selection of more hydrophilic materials to fabricate the artificial compost with thinner tubular particles is of great importance towards optimum water supply in the soil.

Unwetted porosity is defined as the difference between the bed porosity and water-holding porosity, obtained from the water-holding capacity normalized by the volume of the bed. The unwetted porosities and water-holding porosities of the beds composed of various ratios of the quartz sand and the HFMP are shown in Figure 3. The water-holding porosity decreased with the increase of the HFMP fraction, relevant to the water-holding capacity experimental results. Contrarily, the unwetted porosity improved with the addition of the HFMP, which suggests that the bed with a higher HFMP fraction is less likely to retain water. The unwetted porosity increase in the bed with a higher HFMP fraction also implies that water is expected to flow through the interparticle spaces instead of via the micro-sized channels present in the HFMP. Similar to another study conducted by Fauzan et al. (2020), the unwetted porosity of the bed composed of sand and compost particles with a size range of $125-250 \mu \mathrm{m}$ increases with the addition of compost particles. The results indicate that compost can provide more soil spaces by amending interparticle spaces and supplying micro-sized channels to store some nutrients required by plants and ease the gas diffusion in the soil.

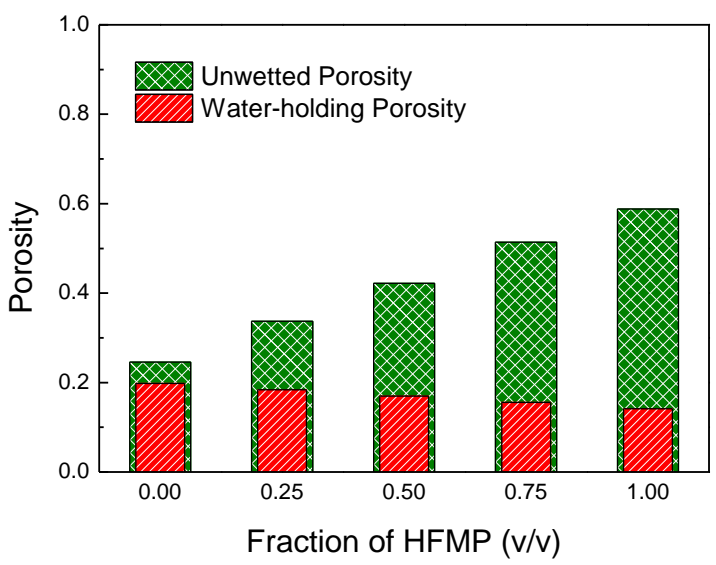

Figure 3. Comparison of the unwetted porosities and water-holding porosities of beds composed of various volumetric ratios of quartz sand particles and HFMP

\section{Bed Permeability}

Falling-head measurements were conducted to obtain the permeability values of the beds composed of various volumetric ratios of the quartz sand particles and the HFMP. The relationships between $-\ln \frac{h}{h_{o}}$ vs $t$ are depicted in Figure 4. Linear relationships indicate that the plots follow the derived Darcy's equation (Equation 12). The gradient of the line, $K$, increases with the addition of HFMP, which suggests that the addition of HFMP into the bed enhances the water movement throughout the bed particles.

The obtained $K$ values were then employed to calculate the permeability values of the beds, as shown in Figure 5. The calculation involved viscosity of water at $25^{\circ} \mathrm{C} \quad(0.0089 \mathrm{~g} / \mathrm{cm} \cdot \mathrm{s})$, gravitational acceleration $\left(980 \mathrm{~cm} / \mathrm{s}^{2}\right)$, density of water at $25^{\circ} \mathrm{C}\left(0.997 \mathrm{~g} / \mathrm{cm}^{3}\right)$, and height of the beds $(10 \mathrm{~cm})$. The results show that the permeability of the bed increases with the addition of HFMP, which implies that quartz sand supplemented with micro-sized pipes have improved water motion. This characteristic is essential in artificial fertilizer design, which can ease nutrient 
delivery between plant roots and water in the soil.

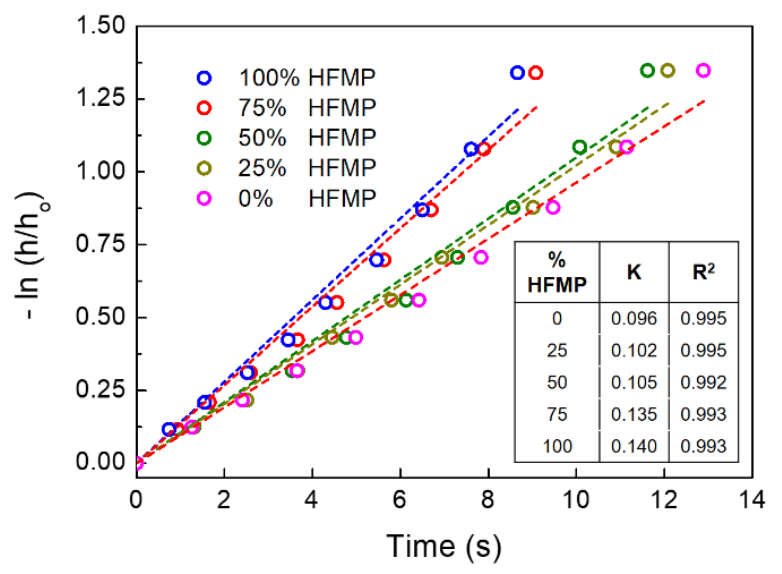

Figure 4. $-\ln \frac{h}{h_{o}} v s t$ curves of beds composed various volumetric ratios of quartz sand particles and HFMP. In the inset, the gradients of the lines $(K)$ and $R^{2}$ are summarized

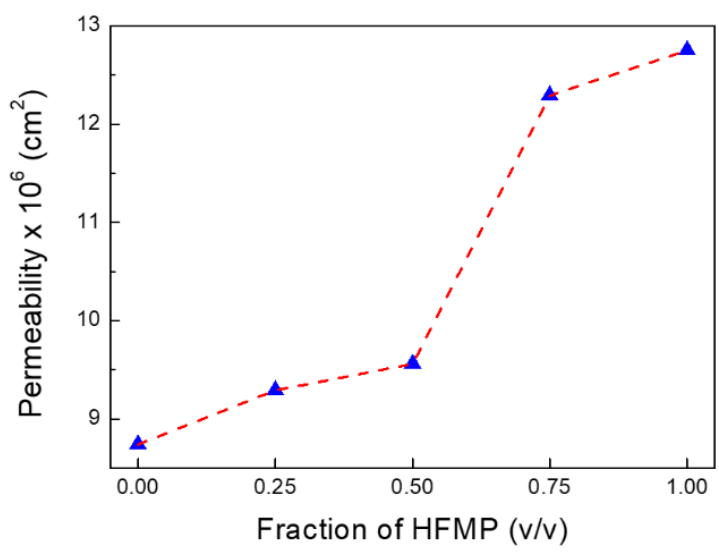

Figure 5. Permeability values of beds composed of various volumetric ratios of quartz sand particles and HFMP

A dramatic increase of the bed permeability was noticed in the bed with an HFMP fraction of 0.75 . The results indicate that the beds with HFMP to quartz sand particles volumetric ratio of above 1 are more likely to have more flexible textures due to the higher elasticity of the polymer material. The elasticity of the HFMP can relieve the water flow during water penetration into the bed. Aranyos et al. (2016) also reported that a higher dose of sewage sludge compost could improve the permeability of sandy soil and other physical properties of the soil. Our previous study also verified that soil supplemented with a higher fraction of compost exhibited enhanced permeability (Purwasasmita, 2015). In another study conducted by Chaganti et al. (2015), using a leaching column experiment with saline-sodic soil, the application of $75 \mathrm{t}$ $\mathrm{ha}^{-1}$ of a biosolids co-compost and a green waste compost can increase soil permeability and hydraulic conductivity.

\section{CONCLUSIONS}

In this work, the performance of artificial compost in enhancing the hydrodynamics of soil was demonstrated using various volumetric ratios of hollow fiber membrane pipes and quartz sand mixtures. The results indicate that the addition of the micro-sized pipes into the bed greatly improved the bed porosity and permeability. The reduction of waterholding capacity in the beds supplemented with a higher fraction of polypropylene-based micro-pipes suggests that hydrophobic materials are less desirable in artificial compost design. Further studies employing shorter microsized pipes $(<10 \mathrm{~mm}$ length) are required to understand the effects of the pipe length on the actual hydrodynamics of the bed.

\section{ACKNOWLEDGEMENTS}

The authors thank the Directorate General of Higher Education Indonesia for financial supports. All authors would like to thank Prof. I Gede Wenten from Institut Teknologi Bandung for the provision of polymer membranes. In memory of our mentor Prof. Mubiar Purwasasmita (deceased), who had significantly contributed to the conceptualization of this research. 


\section{REFERENCES}

Aranyos, J. T.; Tomocsik, A.; Makadi, M.; Meszaros, J.; \& Blasko, L., 2016. Changes in physical properties of sandy soil after long-term compost treatment. Int. Agrophys., (30): 269 274.

Chaganti, V. N.; Crohn, D. M.; \& Simunek, J., 2015. Leaching and reclamation of a biochar and compost amended saline-sodic soil with moderate SAR reclaimed water. Agric. Water Manag., (158): 255265.

Fauzan, A.; \& Rispiandi, R., 2020. The influence size and composition of bioreactor from sand and compost to improve hold up liquid of bed. IOP Conf. Ser.: Mater. Sci. Eng., (830): 022016.

Kahavita, K. D. H. N.; Samarasekara, A. M. P. B.; Amarasinghe, D. A. S.; \& Karunanayake, L., 2019. Influence of surface modification of cellulose nanofibers (CNF) as the reinforcement of polypropylene based composite. 2019 Moratuwa Engineering Research Conference (MERCon), (1): 99-104.

Mosaddeghi, M. R.; Hajabbasi, M. A.; Hemmat, M.; \& Afyuni, M., 2000. Soil compactibility as affected by soil moisture content and farmyard manure in central Iran. Soil Tillage Res., (55): 87-97.

Nawaz, M.F., Bourrié, G. \& Trolard, F., 2013. Soil compaction impact and modelling. A review. Agron. Sustain. Dev., (33): 291-309.

Pambayun, W. S.; Purwasasmita, M.; \& Urahman, T., 2015. Hydordynamic analysis of compost soil mixture and its implication on growth and potassium uptake in corns (Zea mays L.). MATTER: Sci. Eng., (1): 35-47.

Pourjavadi, A.; Doulabi, M.; Soleyman, R.; Sharif, S.; \& Eghtesadi, S. A., 2012. Synthesis and characterization of a novel (salep phosphate)-based hydrogel as a carrier matrix for fertilizer release. React. Funct. Polym., (72): 667-672.

Purwasasmita, M.; \& Hadi, K., 2015. Model hidrodinamika bioreator tanaman: konsep peremeabilitas. Reaktor, (15): 154-164.

Torres, F. G.; Troncoso, O. P.; Torres, C.; Diaz, D. A.; \& Amaya, E., 2011. Biodegradability and mechanical properties of starch films from Andean crops. Int. J. Biol. Macromol., (48): 603-606.

Tschapek, M.; Wasowksi, C.; \& Falasca, S., 1983. Character and change in the hydrophilic properties of quartz sand. Z. Pflanzenernaehr. Bodenk., (146): 295-301.

Yan, Z.; Liu, C.; Todd-Brown, K. E.; Liu, Y.; Bond-Lamberty, B.; Bailey, V. L., 2016. Pore-scale investigation on the response of heterotrophic respiration to moisture conditions in heterogeneous soils. Biogeochemistry, (131): 121-134.

Yamamoto, C. F.; Pereira, E. I.; Mattoso, L. H. C.; Matsunaka, T.; \& Ribeiro, C., 2016. Slow release fertilizers based on urea/urea-formaldehyde polymer nanocomposites. Chem. Eng. J., (287): 390-397.

Yu, Y.; Zhao, C.; Zhao, Z.; Yu, B.; \& Zhou, T., 2015. Soil respiration and the contribution of root respiration of cotton (Gossypium hirsutum L.) in arid region. Acta Ecol. Sin., (35): 1721.

Zhang, X.; Ge, J.; Zhang, S.; Zhao, Y.; Cui, H.; Wei, Z.; Luo, S.; \& Cao, J., 2019. Bioavailability Evaluation of Dissolved Organic Matter Derived from Compost-Amended Soils. $J$. Agric. Food Chem., (67): 59405948. 